\title{
Pengaruh Laba Kotor, Laba Tunai Dan Laba Setelah Pajak Terhadap Dividen Kas Pada Perusahaan Barang Konsumsi Yang Terdaftar Di Bursa Efek Indonesia
}

\author{
Dra. Siti Patimah, MM \\ NIDN : 1130086701 \\ Sitipatimah6767@yahoo.co.id
}

\begin{abstract}
ABSTRAK
Siti Patimah. Pengaruh Laba Kotor, Laba Tunai dan Laba Setelah Pajak terhadap Dividen Kas pada perusahaan Barang Konsumsi yang terdaftar di Bursa Efek Indonesia.

Tujuan penelitian ini adalah untuk menganalisis pengaruh Laba Kotor, Laba Tunai dan Laba Setelah Pajak terhadap Dividen Kas pada perusahaan Barang Konsumsi . Teknik Sampling yang digunakan adalah purposive sampling dengan kriteria Perusahaan Barang Konsumsi yang terdaftar di Bursa Efek Indonesia yang selalu menyajikan laporan keuangan tahun buku berakhir 31 Desember selama periode 2010 - 2012. Diperoleh jumlah sampel sebanyak 10 perusahaan Barang Konsumsi. Teknik analisis yang digunakan adalah analisis regresi berganda dan uji hipotesis menggunakan uji t secara parsial, uji $\mathrm{F}$ secara simultan dengan level of significance 5\% dan uji koefisien determinasi.

Dari hasil analisis menunjukkan bahwa data Laba Kotor, Laba Tunai dan Laba Setelah Pajak secara parsial tidak memiliki pengaruh terhadap Dividen Kas pada perusahaan Barang Konsumsi. Sementara secara simultan Laba Kotor, Laba Tunai dan Laba Setelah Pajak terbukti berpengaruh signifikan terhadap Dividen Kas pada Perusahaan Barang Konsumsi yang terdaftar di Bursa Efek Indonesia pada level kurang dari $5 \%$ yaitu sebesar $0.000 \%(55.020>2.975)$. Naik turunnya Dividen Kas dipengaruhi oleh Laba Kotor, Laba Tunai dan Laba Setelah Pajak sebesar $86.4 \%$ dimana nilai $\mathrm{R}^{2}$ sebesar 0.864 .

Hasil penelitian ini menerima hipotesis yang pertama diduga Laba Kotor, Laba Tunai dan Laba Setelah Pajak secara simultan memiliki pengaruh yang signifikan terhadap Dividen Kas pada perusahaan Barang Konsumsi yang terdaftar di Bursa Efek Indonesia periode 2010 - 2012 dan hipotesis yang kedua yaitu Laba Setelah Pajak secara parsial memiliki pengaruh yang signifikan terhadap Dividen Kas pada perusahaan Barang Konsumsi yang terdaftar di Bursa Efek Indonesia periode 2010 2012.
\end{abstract}

Kata kunci : Laba Kotor, Laba Tunai, Laba Setelah Pajak dan Dividen Kas

ABSTRACT

Jurnal Ilmiah Akuntansi dan Keuangan, Vol.6, No.1, Bulan Juli 2017

Page 22 
Siti Patimah. Effect of Gross Profit, Cash Profit and Earning After Tax to Cash Dividend of Consumer Goods Companies listed on the Indonesian.

The Purpose of this study was to analyze the effect of Gross Profit, Cash Profit and Earning After Tax to Cash Dividend of Consumer Goods Companies . Sampling technique used was purposive sampling criteria and Consumer Good Companies are listed on the Stock Exchange which is always present financial year ending 31 December during the observation period (2010-2012). Retrieved Sample number of 10 companies Consumer Goods. Analysis technique used is multiple regression analysis and hypothesis testing using $t$ tes partially, the $F$ test simultaneously with the level of significance of $5 \%$ and the coefficient of determination test.

From the analysis indicates that the data is partially Gross Profit, Cash Profit and Earning After Tax has no influence on Cash Dividend in the Consumer Good Companies. While Simultaneously (Gross Profit, Cash Profit and Earning After Tax) proved significant effect on Cash Dividend Consumer Good Companies listed on the Stock Exchange at the level of less than 5\% that is equal 0.000\% (55.020 > 2.975). Rise and fall of Cash Dividend is influenced by Gross Profit, Cash Profit and Earning After Tax of $86.4 \%$ where the value $R^{2}$ for 0.864 .

The results of this study received the first Hypothesis that allegedly Gross Profit, Cash Profit and Earning After Tax simultaneously had a significant effect on the Cash Dividen in the Consumer Good Companies listed on the Indonesian Stock Exchange and the period 2010-2012. The second hypothesis is Earning After Tax partially has influence to Cash Dividend in the Consumer Good Companies listed on the Indonesian Stock Exchange and the period 2010-2012.

Key Words : Gross Profit, Cash Profit, Earning After Tax and Cash Divident

\section{PENDAHULUAN}

Perusahaan untuk dapat tumbuh dan berkembang dalam menjalankan usahanya membutuhkan dana yang cukup besar. Oleh sebab itu, perusahaan senantiasa dihadapkan pada permasalahan mengenai bagaimana memperoleh, menggunakan, dan mengembalikan dana yang diperoleh tersebut dengan suatu tingkat pengembalian yang dapat memuaskan pihak pemberi dana. Cara untuk memperoleh dana salah satunya adalah dengan menerbitkan dan menjual saham melalui Pasar Modal atau Bursa Efek sebagai perantara.

Dengan membeli saham sebuah perusahaan, investor secara otomatis ikut serta dalam perusahaan tersebut dan ia mempunyai hak untuk mendapat bagian keuntungan yang dikenal sebagai dividen. Investor lebih memilih Dividen yang berupa kas dibandingkan dengan capital gain. Perilaku ini diakui oleh Gordon-Litner sebagai "The bird in the hand theory" 
bahwa satu burung di tangan (dividen saat ini) lebih berharga daripada seribu burung di udara (capital gains dimasa yang akan datang) artinya bahwa mendapatkan dividen adalah lebih baik dari pada saldo laba karena pada akhirnya saldo laba tersebut mungkin tidak akan pernah terwujud sebagai masa depan. Selain itu investor juga dapat mengevaluasi kinerja perusahaan dengan menilai besarnya dividen yang dibagikan.

Menurut pengertian akuntansi konvensional dinyatakan bahwa laba akuntansi adalah perbedaan antara pendapatan yang dapat direalisir yang dihasilkan dari transaksi dalam suatu periode dengan biaya yang layak dibebankan kepadanya. Bila dilihat secara mendalam, laba akuntansi bukanlah definisi yang sesungguhnya dari laba melainkan hanya merupakan penjelasan mengenai cara untuk menghitung laba (Muqodim, 2005:114). Laba bersih adalah laba setelah dikurangi berbagai pajak.

Laba tunai adalah laba akuntansi setelah disesuaikan dengan transaksi non kas, seperti beban penyusutan, beban amortisasi, beban gaji, penjualan kredit, beban pajak, dan beban bunga yang belum dibayar serta pembelian kredit. Laba tunai yang dimaksud dalam penelitian ini adalah laba yang didapat dari laba akuntansi ditambah dengan beban penyusutan dan amortisasi. Laba Setelah Pajak Atau Laba Bersih, Laba Bersih adalah laba setelah dikurangi berbagai pajak.

Berdasarkan uraian di atas penulis tertarik untuk meneliti "Pengaruh laba kotor, laba tunai dan laba setelah pajak terhadap dividen kas pada Perusahaan Barang Konsumsi yang terdaftar di Bursa Efek Indonesia.

\section{B. Rumusan Masalah}

Berdasarkan uraian latar belakang di atas, maka penulis merumuskan permasalahan sebagai berikut:

1. Apakah laba kotor, laba tunai dan laba setelah pajak berpengaruh secara simultan terhadap dividen kas Pada Perusahaan Barang Konsumsi Yang Terdaftar di Bursa Efek Indonesia?

2. Apakah laba kotor, laba tunai dan laba setelah pajak berpengaruh secara parsial terhadap dividen kas Pada Perusahaan Barang Konsumsi Yang Terdaftar di Bursa Efek Indonesia?

\section{Tujuan Penelitian}

Berdasarkan permasalahan yang telah diuraikan, maka tujuan penelitian ini adalah:

1. Untuk mengetahui apakah terdapat pengaruh laba kotor, laba tunai dan laba setelah pajak secara simultan terhadap dividen kas pada Perusahaan Barang Konsumsi yang terdaftar di Bursa Efek Indonesia.

2.Untuk mengetahui apakah terdapat pengaruh laba kotor, laba tunai dan laba setelah pajak secara parsial terhadap dividen kas pada Perusahaan Barang Konsumsi yang terdaftar di Bursa Efek Indonesia. 
3.Hasil Penelitian ini dapat memberikan pengetahuan dan pemahaman tentang perilaku Pasar Modal khususnya mengenai kebijakan dividen.

4. Bagi Investor maupun calon investor, sebagai pertimbangan dalam pengambilan keputusan untuk membeli, menjual atau menahan saham bedasarkan harapan atas dividen kas yang dibagikan menggunakan informasi laba kotor dan laba tunai yang dilaporkan perusahaan.

\section{TINJAUAN PUSTAKA}

\section{Perusahaan Barang Konsumsi}

Perusahaan Barang konsumsi ialah yaitu perusahaan yang membuat barang yang dipakai secara langsung atau tidak langsung oleh konsumen untuk keperluan pribadi atau rumah tangga yang bersifat sekali habis atau barang yang dibeli untuk konsumsi akhir.

Penggolongan barang konsumsi 0leh Hector Lazo, MBA, Ph.D., dalam bukunya Marketing yaitu:

-a. Barang tahan lama (Durable goods). Barang tahan lama merupakan barang berwujud yang biasanya dapat bertahan lama dengan banyak pemakaian (umur ekonomisnya untuk pemakaian normal adalah 1 tahun atau lebih). Contohnya antara lain adalah televisi, lemari es, mobil, komputer, dan lain-lain. Umumnya jenis barang ini

membutuhkan personal selling dan pelayanan yang lebih banyak daripada barang tidak tahan lama, memberikan keuntungan yang lebih besar, dan membutuhkan jaminan atau garansi tertentu dari penjualnya.

b. Barang tidak tahan lama (Non-Durable goods). Barang tidak tahan lama adalah barang berwujud yang biasanya habis dikonsumsi dalam satu atau beberapa kali pemakaian. Dengan kata lain, umur ekonomisnya dalam kondisi pemakaian normal kurang dari 1 tahun. Contohnya adalah sabun, minuman dan makanan ringan, kapur tulis, gula, dan garam. Oleh karena barang ini dikonsumsi dengan cepat (dalam waktu singkat) dan frekuensi pembeliannya sering terjadi, maka strategi yang paling tepat adalah menyediakannya di banyak lokasi, menerapkan markup yang kecil, dan mengiklankannya secara gencar untuk merangsang orang agar mencobanya dan sekaligus untuk membentuk preferensi.

c. Barang jasa (service goods). Jasa merupakan aktivitas, manfaat atau kepuasan yang ditawarkan untuk dijual. Contohnya bengkel reparasi, 
salon kecantikan, kursus, hotel, lembaga pendidikan, dll (Kotler, $1997: 54$ ).

Berdasarkan kriteria ini, produk dapat dibedakan menjadi barang konsumen (consumer's goods) dan barang industri (industrial's goods).

Hector Lazo membagi lagi barang-barang tersebut di atas menjadi:

goods

- Convenience

- Shopping goods

- Specialty goods

Kotler (2000:397), membedakan klasifikasi barang konsumsi sebagai berikut:

- Convenience goods

- Shopping goods

- Specialty goods

- Barang yang tidak dicari (Unsought goods).

Barang konsumen adalah barang yang dikonsumsi untuk kepentingan pelanggan akhir sendiri (individu dan rumah tangga), bukan untuk tujuan bisnis. Umumnya barang pelanggan dapat diklasifikasikan menjadi 4 jenis, yaitu:

1. Convenience goods

\section{Convinience}

goods merupakan barang yang pada umumnya memiliki frekuensi pembelian yang tinggi (sering dibeli), dibutuhkan dalam waktu segera, dan hanya memerlukan usaha yang minimum (sangat kecil) dalam pembandingan dan pembeliannya. Contohnya antara lain rokok, sabun, pasta gigi, baterai, permen, dan surat kabar. Convinience goods sendiri masih dapat dikelompokkan menjadi tiga jenis, yaitu :

a.

Staples adalah barang yang dibeli ko nsumen secara reguler atau rutin, misalnya sabun mandi dan pasta gigi.

b. Impulse

goods merupakan barang yang dibeli tanpa perencanaan terlebih dahulu ataupun usaha-usaha mencarinya.

Biasanya Impulse goods tersedia dan dipajang di banyak tempat yang tersebar, sehingga konsumen tidak perlu repot-repot mencarinya. Contohnya permen, coklat, majalah.

c. Emergency

goods adalah barang yang dibeli bila suatu kebutuhan dirasa sangat mendesak, misalnya payung dan jas hujan di musim hujan.

2. Shopping goods Shopping goods adalah barang-barang yang dalam proses pemilihan 
dan pembeliannya konsumen bersedia membuang waktunya untuk memilihmilih. Untuk membeli barang ini biasanya telah direncanakan lebih dulu. Kriteria perbandingan tersebut meliputi harga, kualitas, dan model masingmasing barang. Contohnya alat-alat rumah tangga, pakaian, dan furniture. Shopping goods terdiri atas dua jenis, yaitu :

a. Homogeneous shopping goods merupakan barang-barang yang oleh konsumen dianggap serupa dalam hal kualitas tetapi cukup berbeda dalam harga. Dengan demikian konsumen berusaha mencari harga yang termurah dengan cara membandingkan harga di satu toko dengan toko lainnya. Contohnya adalah tape recorder, TV, dan mesin cuci.

b. Heterogeneous

shopping goods adalah barang-barang yang aspek karakteristik atau ciri-cirinya (features) dianggap lebih penting oleh konsumen daripada aspek harganya. Dengan kata lain, konsumen mempersepsikannya

berbeda dalam hal kualitas dan atribut. Contohnya

perlengkapan rumah tangga, mebel, dan pakaian.

3. Specialty goods

\section{Specialty}

goods adalah barang-barang yang memiliki karakteristik dan / atau identifikasi merek yang unik dimana sekelompok konsumen bersedia melakukan usaha khusus untuk membelinya. Umumnya specialty

goods terdiri atas barangbarang mewah dengan merek dan model spesifik, seperti mobil Lamborghini, kamera Nikon, dan lain-lain.

4. Unsought goods Unsought

goods merupakan barangbarang yang tidak diketahui konsumen atau kalaupun sudah diketahui, tetapi pada umumnya belum terpikirkan untuk membelinya. Ada dua jenis unsought goods, yaitu :

1. Regularly unsought goods adalah barangbarang yang sebetulnya sudah ada dan diketahui konsumen, tetapi tidak terpikirkan untuk membelinya. Contohnya ensiklopedia, asuransi jiwa, batu nisan, tanah kuburan. 


\section{New unsought goods adalah barang yang benar-benar baru dan sama sekali belum diketahui konsumen. Jenis barang ini merupakan hasil inovasi dan pengembangan produk baru, sehingga belum banyak konsumen yang mengetahuinya.}

\section{Laporan Keuangan}

adalah laporan yang berisi
informasi keuangan sebuah organisasi. Laporan keuangan yang diterbitkan oleh perusahaan merupakan hasil proses akuntansi yang dimaksudkan sebagai sarana mengkomunikasikan informasi keuangan terutama kepada pihak eksternal. Soemarso (2004: 34) "Laporan keuangan adalah laporan yang dirancang untuk para pembuat keputusan, terutama pihak diluar perusahaan, mengenai posisi keuangan dan hasil usaha perusahaan". laporan keuangan menurut PSAK (Pernyataan Standar Akuntansi Keuangan) per 1 Juni 2012 sebagai berikut: "Laporan keuangan merupakan bagian dari proses pelaporan keuangan."

\section{Tujuan Laporan Keuangan}

PSAK per 1 Juni 2012, tujuan laporan keuangan adalah menyediakan informasi yang menyangkut posisi keuangan, kinerja serta perubahan posisi keuangan suatu perusahaan yang bermanfaat bagi sejumlah besar pemakai dalam pengambilan keputusan ekonomi. Laporan keuangan disusun untuk memenuhi kebutuhan bersama sebagian besar pemakai. Namun demikian, laporan keuangan tidak menyediakan semua informasi yang mungkin dibutuhkan pemakai dalam pengambilan keputusan ekonomi karena secara umum menggambarkan pengaruh keuangan dari kejadian di masa lalu, dan tidak diwajibkan untuk menyediakan informasi nonkeuangan.

\section{Manfaat Laporan Keuangan}

Laporan keuangan merupakan alat yang sangat penting untuk mendapatkan informasi sehubungan dengan posisi keuangan dan hasil-hasil yang dicapai oleh perusahaan. Data keuangan tersebut akan lebih berarti jika diperbandingkan dan dianalisis lebih lanjut sehingga dapat diperoleh data yang dapat mendukung keputusan yang diambil.

5. Komponen Laporan Keuangan

PSAK per 1 Juni 2012, "laporan keuangan yang lengkap terdiri dari komponen - komponen berikut ini:
a. Neraca
b. Laporan Laba Rugi
c. Laporan Perubahan
Ekuitas
d. Laporan Arus Kas
e. Catatan atas Laporan
Keuangan

\section{a. Neraca}


Neraca adalah laporan yang berisi harta (aset), utang atau kewajiban-kewajiban pada pihak lain (liabilitas) beserta modal (capital) dari suatu perusahaan pada saat tertentu. Neraca perusahaan disajikan sedemikian rupa yang menggambarkan posisi keuangan suatu perusahaan pada saat tertentu. Hal ini untuk menunjukkan keadaan keuangan pada tanggal tertentu biasanya pada saat tutup buku.

\section{b. Laporan Laba Rugi}

Laporan laba rugi merupakan suatu laporan yang sistematis mengenai penghasilan, biaya, rugi laba yang diperoleh oleh suatu perusahaan selama periode tertentu. Tujuan pokok laporan laba rugi adalah melaporkan kemampuan riil perusahaan dalam menghasilkan keuntungan. Laporan laba rugi perusahan disajikan sedemikian rupa yang menonjolkan berbagai unsur kinerja keuangan yang diperlukan bagi penyajian secara wajar.

\section{c. Laporan Perubahan Ekuitas}

Laporan perubahan ekuitas (modal) adalah laporan yang disusun untuk mengetahui perubahan modal yang dimiliki atau untuk mengetahui modal akhir pada satu periode. Laporan perubahan ekuitas ini dimaksudkan untuk mengetahui perkembangan perusahaan yang dilihat dari hak kepemilikan (modal) selama satu periode akuntansi. Perusahaan harus menyajikan laporan perubahan ekuitas sebagai komponen utama laporan keuangan.

\section{d. Laporan Arus Kas}

Laporan arus kas merupakan laporan keuangan yang berisi informasi aliran kas masuk dan aliran kas keluar dari suatu perusahaan selama periode tertentu. Penyajian informasi dalam laporan ini diklasifikasikan menurut jenis kegiatan yang menyebabkan terjadinya arus kas masuk dan kas keluar tersebut. Aktivitas perusahaan umumnya terdiri dari tiga jenis yaitu aktivitas operasional, aktivitas investasi serta aktivitas pendanaan. Informasi arus kas berguna untuk menilai kemampuan perusahaan dalam menghasilkan kas dan setara kas dan memungkinkan para pemakai mengembangkan model untuk menilai dan membandingkan nilai sekarang dari arus kas masa depan (future cash flow) dari berbagai perusahaan.

e. Catatan Atas Laporan Keuangan

Catatan atas laporan keuangan adalah catatan tambahan dan informasi yang ditambahkan ke akhir laporan 
keuangan untuk memberikan tambahan informasi kepada pembaca guna memperoleh informasi lebih lanjut. Catatan atas laporan keuangan harus disajikan secara sistematis. Setiap pos dalam neraca, laporan laba rugi dan laporan arus kas harus berkaitan dengan informasi yang terdapat catatan atas laporan keuangan.

\section{Laba Akuntansi}

Akuntansi konvensional dinyatakan bahwa laba akuntansi adalah perbedaan antara pendapatan yg dapat direalisir yg dihasilkan dari transaksi dalam suatu periode dengan biaya yang layak dibebankan kepadanya (Muqodim 2005:111). Suwardjono (2005:455) mendefinisian laba sebagai pendapatan dikurangi biaya merupakan pendefinisian secara struktural atau sintaktik karena laba tak didefinisi secara terpisah dari pengertian pendapatan dan biaya. Pengertian laba yang dianut oleh struktur akuntansi sekarang ini adalah laba yang merupakan selisih pengukuran pendapatan dan biaya secara akrual.

Ada dua ukuran kinerja akuntansi perusahaan yaitu laba akuntansi dan total arus kas. Ahmed Belkaoui (2000:332) menyatakan bahwa laba akuntansi secara operasional didefinisikan sebagai perbedaan antara pendapatan yang direalisasikan yang berasal dari transaksi suatu periode dan berhubungan dengan biaya historis.

Beberapa keunggulan laba akuntansi yang dikemukakan oleh Muqodim (2005 : 114) adalah:

1) Terbukti teruji sepanjang sejarah bahwa laba akuntansi bermanfaat bagi para pemakainya dalam pengambilan keputusan ekonomi.

2) Laba akuntansi telah diukur dan dilaporkan secara obyektif dapat diuj kebenarannya sebab didasarkan pada transaksi nyata yang didukung oleh bukti.

3) Berdasarkan prinsip realisasi dalam mengakui pendapatan laba akuntansi memenuhi dasar konservatisme.

4) Laba akuntansi bermanfaat untuk tujuan pengendalian terutama berkaitan dengan pertanggungjawaban manajemen.

\section{a. Laba Kotor}

Dalam pengertian secara umum, laba kotor dikatakan sebagai kelebihan penjualan bersih terhadap harga pokok penjualan. Menurut Wild, et.al (2005:120)"Laba kotor merupakan pendapatan dikurangi harga pokok penjulan". Oleh karena itu dapat disimpulkan bahwa laba kotor dalam penelitian ini merupakan selisih antara 
pendapatan bersih dengan harga pokok penjualan (Soemarso, 2004:226).

b. Laba Tunai

Evans $\quad$ (2003:199)

"Cash Income is strictly objective. It is based on cash inflows and outflows. Cash Realzaton is the only trigger for recognition of income". Laba tunai adalah laba akuntansi setelah disesuaikan dengan transaksi-transaksi nonkas, seperti bebas penyusutan, beban amortisasi, penjualan kredit, beban gaji, beban pajak, dan beban bungan yang belum dibayar, serta pembelian kredit.

Laba tunai yang dimaksud pada penelitian ini adalah laba akuntansi setelah disesuaikan dengan transaksi non kas, seperti beban penyusutan, beban amortisasi, utang gaji, penjualan kredit, beban pajak, dan beban bunga yang belum dibayar serta pembelian kredit. Laba tunai merupakan arus kas dari aktivitas operasi perusahaan (Soemarso, 2005:44).

\section{c. Laba Setelah Pajak}

Laba setelah pajak (EAT) adalah laba yang diperoleh oleh perusahaan setelah dikurangi dengan pajak.

Adapun faktor - faktor yang mempengaruhi EAT (Earning After Tax) terdiri dari : a. Sales (Penjualan)

b. COGS (Cost of Good Sold)

c. General expanses/operational expense (Biaya Operasional)

d. Interest (bunga)

e. Tax (pajak)

Harahap (2004: 335)

laba setelah pajak dihitung dari : Laba setelah pajak $=$ Penjualan$$
\text { operasi+bunga+pajak }
$$

penghasilan)

Laba Setelah Pajak dalam penelitian ini disebut juga sebagai Laba Bersih, Laba Bersih adalah laba setelah dikurangi berbagai pajak.

\section{Dividen Kas}

Saham Dividen adalah proporsi laba atau keuntungan yang dibagikan kepada para pemegang saham dalam jumlah yang sebanding dengan jumlah lembar saham yang dimilikinya (Baridwan, 2000:434).

Kebijakan pembagian dividen adalah suatu keputusan untuk menentukan berapa besar bagian laba akan dibagikan kepada para pemegang saham dan akan ditahan dalam perusahaan selanjutnya diinvestasikan kembali (Husnan,1994). Kebijakan pembagian dividen tergantung pada keputusan rapat umum pemegang saham (RUPS).

Kebijakan dividen penting bagi perusahaan dengan dua alasan, yaitu: 
1. Pembayaran dividen mungkin akan mempengaruhi nilai perusahaan yang tercermin dari harga saham perusahaan tersebut.

2. Laba ditahan biasanya merupakan sumber dana internal yang terbesar dan terpenting bagi pertumbuhan perusahaan.

Menurut Riyanto (2002:62) beberapa hal yang menjadi dasar pertimbangan kebijakan dividen antara lain; adanya perjanjian (misalnya hutang) yang mensyaratkan untuk menahan sebagian/seluruh laba, kebutuhan dana bagi perusahaan, likuiditas perusahaan, sifat pemegang saham, stabilitas dividen, atau target tertentu mengenai rasio pembayaran dividen. Kebijakan dividen merupakan bagian yang menyatu dengan keputusan pendanaan perusahaan. Rasio pembayaran dividen menentukan jumlah laba yang dapat ditahan sebagai sumber pendanaan.

\section{B. Hipotesis}

Dengan melihat permasalahan yang ada, maka hipotesis yang penulis buat adalah sebagai berikut :

1. Diduga bahwa variabel Laba Kotor, Laba Tunai dan Laba Setelah Pajak secara simultan memiliki pengaruh yang signifikan terhadap Dividen Kas Pada Perusahaan Barang
Konsumsi Yang Terdaftar di Bursa Efek Indonesia.

2. Diduga Laba Kotor, Laba Tunai dan Laba Setelah Pajak secara parsial memiliki pengaruh terhadap Dividen Kas Pada Perusahaan Barang Konsumsi Yang Terdaftar di Bursa Efek Indonesia.

\section{Definisi Konsepsional}

Konsep merupakan dasar acuan dari sebuah penelitian dimana penentuan dan perincian agar persoalan dan pembahasan lebih terarah. Untuk memberikan gambaran tentang penelitian serta gagasan yang jelas mengenai variabel-variabel yang digunakan dalam penelitian ini, maka diberi batasan konsepsional sebagai berikut :

1. Laba Kotor

Laba kotor merupakan selisih antara penjualan bersih dengan harga pokok penjualan (Soemarso, 2004:226).

2. Laba Tunai

Evan (2003:199) laba tunai adalah laba akuntansi setelah diperhitungkan dengan beban - beban non kas seperti baban amortisasi, beban penyusutan, penjualan kredit, beban gaji, beban pajak, dan beban bunga yang belum dibayar, serta pembelian kredit. Penyusutan merupakan pengalokasian biaya dari aktiva berwujud, sedangkan amortisasi menyusutkan jumlah dari aktiva yang tidak berwujud. 
Arus kas bersih $=$ Laba

bersih - Pendapatan non kas + Beban non kas

3. Laba Setelah Pajak

Laba Setelah Pajak Atau

Laba Bersih, Laba Bersih adalah laba setelah dikurangi berbagai pajak.

4. Dividen Kas

Tangkilisan dan Hessel (2003:227) “ Dividen adalah bagian dari laba bersih yang dibagikan kepada para pemegang saham (pemilik modal sendiri,equity)."

\section{METODOLOGI PENELITIAN}

\section{A. Definisi Operasional}

Kinerja keuangan adalah suatu prestasi atau hasil dari keadaan keuangan perusahaan. Pencerminan kinerja keuangan pada Perusahaan Barang Konsumsi yang terdaftar di Bursa Efek Indonesia direfleksikan melalui definisi operasional variabel. Definisi operasional adalah konsep yang diubah sehingga dapat diukur secara empiris. Dalam penelitian ini akan diberikan suatu perumusan atau definisi operasional mengenai variabel-variabel yang dianalisis sebagai berikut :

1. Variabel Independen (Bebas)

Sugiyono (2008:59)

"Variabel bebas adalah merupakan variabel yang mempengaruhi atau menjadi sebab perubahannya atau timbulnya variabel dependen (terikat)". Variabel independen dalam penelitian ini adalah laba kotor $\left(\mathrm{X}_{1}\right)$, laba tunai $\left(\mathrm{X}_{2}\right)$, dan Laba Setelah Pajak $\left(X_{3}\right)$.

Laba kotor $\left(\mathrm{X}_{1}\right)$ yang digunakan dalam penelitian ini adalah Laba kotor merupakan selisih antara penjualan bersih dengan harga pokok penjualan pada Perusahaan Barang Konsumsi yang terdaftar di Bursa Efek Indonesia pada tahun 2010 - 2012.

Laba tunai $\left(\mathrm{X}_{2}\right)$ yang digunakan dalam peneltian ini adalah laba akuntansi setelah disesuaikan dengan transaksi transaksi non kas, seperti beban penyusutan, beban amortisasi, penjualan kredit, beban gaji, beban pajak dan beban bunga yang belum dibayar, serta pembelian kredit. Informasi tentang laba tunai ini diperoleh dari jumlah arus kas dari aktivitas operasi pada laporan arus kas Perusahaan Barang Konsumsi yang terdaftar di Bursa Efek Indonesia pada tahun 2010 - 2012.

Laba Setelah Pajak $\left(\mathrm{X}_{3}\right)$
digunakan dam penelitian ini adalah laba bersih yaitu laba setelah dikurangin berbagai pajak.

2. Variabel Dependen (Terikat)

Sugiyono (2008:59)

"Variabel terikat merupakan variabel yang dipengaruhi atau yang menjadi akibat, karena adanya variabel bebas".

Dividen kas (Y) ialah laba yang dibagikan kepada pemegang saham berdasarkan hasil keputusan rapat umum 
pemegang saham dalam bentuk kas.

\section{B. Populasi dan Sampel}

\section{Populasi}

Populasi adalah wilayah generalisasi yang terdiri atas obyek/subyek yang mempunyai kualitas dan karakteristik tertentu yang ditetapkan oleh peneliti untuk dipelajari dan kemudian ditarik kesimpulannya (Sugiyono, 2008:115). Populasi dalam penelitian ini adalah perusahaan yang masuk dalam kategori perusahaan barang konsumsi berdasarkan klasifikasi pada Indonesian Capital Market Directory (ICMD) di Bursa Efek Indonesia.

\section{Tabel 3.1}

Nama Perusahaan Populasi

\begin{tabular}{|c|l|}
\hline No. & \multicolumn{1}{|c|}{ Nama Perusahaan } \\
\hline 1 & PT. Delta Djakarta, Tbk \\
\hline 2 & PT. Tiga Pilar Sejahtera Food, Tbk \\
\hline 3 & PT. Tri Banyan Tirta, Tbk \\
\hline 4 & PT. Cahaya Kalbar, Tbk \\
\hline 5 & PT. Davomas Abadi, Tbk \\
\hline 6 & PT. Indofood CBP Sukses Makmur, Tbk \\
\hline 7 & PT. Indofood Sukses Makmur, Tbk \\
\hline 8 & PT. Multi Bintang Indonesia, Tbk \\
\hline 9 & PT. Mayora Indah, Tbk \\
\hline 10 & PT. Parasidha Aneka Niaga, Tbk \\
\hline 11 & PT. Nippon Indosari Corpindon, Tbk \\
\hline 12 & PT. Sekar Bumi, Tbk \\
\hline 13 & PT. Sekar Laut, Tbk \\
\hline 14 & PT. Siantor Top, Tbk \\
\hline 15 & PT. Ultra Jaya Milk Industri \& Trading Company, \\
\hline 16 & Tbk \\
\hline 17 & PT. Akasha Wira Internasional, Tbk \\
\hline 18 & PT. Handjaya Mandala Sampoerna, Tbk \\
\hline 19 & PT. Bentoel International Investama, Tbk \\
\hline 20 & PT. Wismilak Inti Makmur, Tbk \\
\hline 21 & PT. Darya Varia Laboratoria, Tbk \\
\hline 22 & PT. Indofarma (Persero), Tbk \\
\hline 23 & PT. Kimia Farma (Persero), Tbk \\
\hline 24 & PT. Kalbe Farma, Tbk \\
\hline 25 & PT. Merck, Tbk \\
\hline 26 & PT. Pyridam Farma, Tbk \\
\hline & \\
\hline
\end{tabular}




\begin{tabular}{|l|l|}
\hline 27 & PT. Schering Plough Indonesia, Tbk \\
\hline 28 & PT .Taisho Pharmaceutical Indonesia, Tbk \\
\hline 29 & PT .Tempo Scan Pasific, Tbk \\
\hline 30 & PT. Martina Berto, Tbk \\
\hline 31 & PT. Mustika Ratu, Tbk \\
\hline 32 & PT. Mandom Indonesia, Tbk \\
\hline 33 & PT .Unilever Indonesia, Tbk \\
\hline 34 & PT. Kedawung Setia Industrial, Tbk \\
\hline 35 & PT. Kedaung Indah Can, Tbk \\
\hline 36 & PT .Langgeng Makmur Industry, Tbk \\
\hline
\end{tabular}

\section{Sampel}

Sampel adalah bagian dari jumlah dan karakteristik yang dimiliki oleh populasi tersebut (Sugiyono, 2008:116). Sumarni (2006:77), "Purposive sampling adalah teknik mengambil sampel dengan menyesuaikan diri berdasar kriteria atau tujuan tertentu (disengaja)". Purposive sampling di sini menggunakan judgement sampling, yaitu teknik pengambilan sampel dengan beberapa kriteria tertentu. Sampel yang akan digunakan dalam penelitian ini adalah perusahaanperusahaan barang konsumsi yang terdaftar di Bursa Efek Indonesia. Metode pengambilan sampel menggunakan metode purposive sampling, yaitu metode pengambilan sampel yang tidak acak atau sesuai dengan kriteria tertentu, dari 36 Perusahaan Barang Konsumsi yang terdaftar di Bursa Efek Indonesia yang telah memenuhi kriteria diambil sampel sebagai berikut :

Tabel 3.2

Nama Perusahaan Sampel

\begin{tabular}{|c|l|}
\hline No. & \multicolumn{1}{|c|}{ Nama Perusahaan } \\
\hline 1 & PT. Darya-Varia Laboratoria, Tbk \\
\hline 2 & PT. HM Sampoerna, Tbk \\
\hline 3 & PT. Kimia Farma (Persero), Tbk \\
\hline 4 & PT. Martina Berto, Tbk \\
\hline 5 & PT. Merck, Tbk \\
\hline 6 & PT. Mandom Indonesia, Tbk \\
\hline 7 & PT. Unilever Indonesia, Tbk \\
\hline 8 & PT. Indofood CBP Sukses Makmur, Tbk \\
\hline 9 & PT. Indofood Sukses Makmur, Tbk \\
\hline
\end{tabular}




\section{\begin{tabular}{l|l}
10 & PT. Tempo Scan Pacific, Tbk
\end{tabular}}

C. Lokasi Penelitian

\begin{abstract}
Pengambilan data
dilakukan melalui laporan keuangan tahunan yang telah dipublikasikan di Pusat Informasi Pasar Modal (PIPM) Balikpapan yang berlokasi di jalan Sudirman No.33 B Balikpapan dan melalui publikasi laporan keuangan di situs Bursa Efek Indonesia www.idx.co.id sebagai tempat observasi.
\end{abstract}

\section{Sumber dan Jenis Data}

Data yang dikumpulkan berupa data kuantitatif, yaitu data yang diukur dalam suatu skala numerik (Kuncoro, 2003:124). Sumber data penelitian ini merupakan data sekunder, berupa laporan keuangan tahunan yang dipublikasikan di Pusat Informasi Pasar Modal (PIPM) Balikpapan dan situs Bursa Efek Indonesia periode tahun 2010 sampai tahun 2012.

\section{E. Metode Analisis Data}

$$
\text { Metode penganalisaan }
$$

data yang digunakan dalam penelitian ini adalah metode analisa statistik menggunakan alat bantu komputer program SPSS 19.0 for windows.

1. Statistic Deskriptif

Statistik deskriptif yaitu suatu metode yang berusaha untuk memberikan gambaran secara sistematis dan akurat mengenai faktafakta, sifat, dan hubungan antara fenomena yang diteliti dalam suatu perusahaan.
2. Analisis Regresi Linier Berganda.

Untuk menguji hipotesis faktor-faktor yang mempengaruhi dividen kas digunakan metode analisis regresi berganda, dan model yang digunakan dalam pengujian hipotesis ini adalah sebagai berikut :

Adapun rumus

persamaan regresi adalah sebagai berikut Suharyadi dan Purwanto, (2004:509) :

$$
\mathrm{Y}=
$$

$a+b 1 X 1+b 2 X 2+b 3 X 3+e$

Dari rumus di atas

variable-variabel dapat dinotasikan sebagai berikut :

Y : Variabel dependen ( Dividen Kas )

a : Konstanta atau harga $Y$ bila $\mathrm{X}=0$

b1 : Koefisien regresi laba kotor

b2 : Koefiseien regresi laba tunai

b3 : Koefiseien regresi laba setelah pajak

$\mathrm{X} 1$ : Variabel independen (Laba Kotor)

$\mathrm{X} 2$ : Variabel independen ( Laba Tunai)

$\mathrm{X} 3$ : Variabel independen ( Laba setelah pajak)

e : error

3. Uji Asumsi Klasik Sebelum melakukan analisis regresi perlu di lakukan pengujian asumsi 
klasik sebelumnya. Hal ini di lakukan agar data sampel yang di olah dapat memberikan informasi yang benar-benar valid dan mewakili populasi secara keseluruhan. Adapun asumsi pengujian klasik yang digunakan dalam penelitian ini adalah :

a) Uji Multikolinieritas

Multikolinieritas merupakan keadaan dimana satu atau lebih variable independen dinyatakan sebagai kombinasi linier dengan variable independen lainnya. Berarti jika variabel bebas yang digunakan sama sekali tidak berkorelasi satu dengan yang lain maka bisa dikatakan bahwa tidak terjadi multikolinieritas.

Pengujian

multikolinieritas

menggunakan Varians

Inflation Factor (VIF). Apabila variabel independen memiliki angka VIF disekitar angka 10 dan nilai tolerance mendekati angka $10 \%$, maka dapat dikatakan bahwa variabel independen tidak memiliki

multikolinieritas dengan variabel lain. Uji ini menggunakan rumus sebagai berikut :

$\mathrm{VIF}=\frac{1}{1-R^{2}}$

b) Uji Autokorelasi Autokorelasi

dapat didefinisikan sebagai terjadinya korelasi diantara suatu data dengan data sebelumnya. Jadi pengujian ini bertujuan untuk mengetahui ada tidaknya korelasi antara variabel dan standard error dapat dilakukan dengan menggunakan Durbin - Watson (D-W Stat).

Model dikatakan bebas autokorelasi apabila nilai DW yang didapatkan diantara 2 dan -2. Apabila nilai DW yang didapatkan lebih besar dari 2 atau kecil dari $\quad-2$ maka dibandingkan dengan DW tabel. Jika nilai D-W besar dari +2 maka terjadi autokorelasi negatif, dan jika nilai DW kecil dari - 2 maka terjadi autokorelasi positif. Apabiia nilai DW tabel lebih besar dari nilai batas atas maka model sudah bisa dikatakan bebas autokorelasi.

c) Uji Heteroskedastisitas 


\begin{abstract}
Uji ini bertujuan
untuk menguji apakah

sebuah model regresi

terjadi ketidak samaan

varian dari suatu

pengamatan ke

pengamatan yang lain

tetap. Jika terjadi varians

yang berbeda disebut heteroskedastisitas.

Model regresi ini yang baik adalah terjadi heteroskedastisitas.
\end{abstract}

\section{F. Pengujian Hipotesis}

Uji signifikasi antara

variabel bebas terhadap variabel terikat, baik secara bersama-sama (serentak) maupun secara parsial dapat dilakukan dengan menggunakan uji statistik $F$ dan uji statistik t.

1. Uji F

Uji ini bertujuan untuk menentukan signifikasi pengaruh variabel independen bersama-sama terhadap variabel dependen dengan rumusan hipotesis sebagai berikut:

a. $\mathrm{H}_{0}: \mathrm{b}_{1} \quad \ldots \ldots \mathrm{b}_{4}=0$, berarti variabel yang bergabung dalam variabel $X$, secara simultan (bersama-sama) tidak mempunyai pengaruh yang signifikasi terhadap variabel (Y).

b. $\mathrm{H}_{\mathrm{a}}$ : minimal satu $\mathrm{b}_{1} \# 0$, berarti variabel yang tergabung dalam variabel $\mathrm{X}$, secara bersama-sama mempunyai pengaruh yang

$$
\begin{aligned}
& \text { signifikasi terhadap } \\
& \text { variabel (Y). Tingkat } \\
& \text { signifikasi yang digunakan } \\
& \text { adalah } \alpha=0,05 \text {. Pengujian } \\
& \text { dilakukan dengan } \\
& \text { membandingkan } \quad F_{\text {hitung }} \\
& \text { dengan } F_{\text {tabel }} \text { pada derajat } \\
& \text { bebas monitor }\left(\mathrm{V}_{1}\right)-\mathrm{k}-1 \\
& \text { dan denominator }\left(\mathrm{V}_{2}\right)=\mathrm{n}- \\
& \mathrm{k} \text { - 1, dimana } \mathrm{k} \text { adalah } \\
& \text { banyaknya parameter } \\
& \text { regresi persamaan. Jika } \\
& F_{\text {hitung }}>\mathrm{F}_{\text {tabel }} \text { maka } \mathrm{H}_{0} \\
& \text { ditolak dan } \mathrm{H}_{\mathrm{a}} \text { diterima } \\
& \text { berarti signifikan, } \\
& \text { sedangkan Jika Fhitung < } \\
& \mathrm{F}_{\text {tabel }} \text { maka } \mathrm{H}_{0} \text { diterima dan } \\
& \mathrm{H}_{\mathrm{a}} \text { ditolak berarti tidak } \\
& \text { signifikan. }
\end{aligned}
$$

2. Uji t-statistik

Uji $\mathrm{t}$ digunakan untuk menguji signifikasi pengaruh variabel independen (X) terhadap variabel dependen (Y secara parsial) dengan rumus sebagai berikut:

a. $\mathrm{H}_{0} \quad$ : $\mathrm{b}_{1} \quad \ldots \ldots \ldots \ldots \mathrm{b}_{4}=0$, variabel yang bergabung dengan variabel independen (X) tidak mempunyai pengaruh yang signifikasi terhadap variabel dependen (Y), dengan asumsi variabel independen lainnya dianggap konstan.

b. $\mathrm{H}_{\mathrm{a}}$ : minimal satu $\mathrm{b}_{1} \neq 0$, variabel yang bergabung dengan independen (X) mempunyai pengaruh yang signifikasi terhadap variabel dependen (Y), 
dengan asumsi variabel independen lainnya dianggap konstan.

Tingkat signifikasi yang digunakan adalah alpa $(\alpha)=0,05$ atau $5 \%$. Pengujian dilakukan dengan uji t dengan membandingkan $t_{\text {hitung }}\left(\mathrm{t}_{\mathrm{h}}\right)$ dengan $\mathrm{t}_{\text {tabel }}\left(\mathrm{t}_{\mathrm{t}}\right)$ pada $\quad \alpha$ $=0,05$. Apabila hasil pengujian menunjukkan $t_{\text {hitung }}$ $>t_{\text {tabel, }}$ maka $\mathrm{H}_{0}$ akan ditolak dan $\mathrm{H}_{\mathrm{a}}$ diterima berarti signifikan, sedangkan jika $t_{\text {hitung }}<t_{\text {tabel, }}$ maka $\mathrm{H}_{0}$ akan diterima dan $\mathrm{H}_{\mathrm{a}}$ ditolak berarti tidak signifikan. Variabel $X_{n}$ yang mempunyai nilai thitung paling besar berarti variabel tersebut yang mempunyai pengaruh yang dominan.

3. Uji Koefisien Determinasi $\left(\mathrm{R}^{2}\right)$

$$
\text { Uji ini bertujuan }
$$

untuk mengetahui sejauh mana besarnya sumbangan masing-masing varibel bebas $\mathrm{X}_{1}, \mathrm{X}_{2}, \mathrm{X}_{3}$ dan $\mathrm{X}_{4}$ terhadap variabel tak bebas (Y) dan untuk mengetahui variabel bebas mana yang mempunyai sumbangan terbesar (dominan) terhadap variabel tidak bebas. Berarti semakin besar $\mathrm{R}^{2}$ untuk masing-masing variabel bebas, menunjukkan semakin besar pula sumbangannya terhadap variabel tidak bebas dan jika ada variabel bebas yang angka $\mathrm{R}^{2}$ paling besar, probabilitasnya paling kecil dan thitungnya paling tinggi, maka variabel bebas tersebut mempunyai pengaruh yang dominan terhadap variabel tidak bebasnya.

\section{HASIL DAN PEMBAHASAN}

\section{G. Gambaran Umum Penelitian}

1. Bursa Efek Indonesia

PT. Bursa Efek Indonesia sebelumnya diberi nama PT. Bursa Efek Jakarta Perseroan didirikan berdasarkan akta pendirian No. 27 dihadapan Ny. Titi Poerbaningsih Adi Warsito, $\mathrm{SH}$, Notaris di Jakarta pada tanggal 04 Desember 1991. Kedudukan perseroan sebagai badan hukum telah disahkan oleh Menteri Kehakiman RI No. C2 8146 HT.10.01, tanggal 26 Desember 1991 dan dimuat dalam Tambahan Berita Acara Negara Republik Indonesia No.1355 tanggal 27 Maret 1992. Perseroan resmi mendapat izin usaha dari Menteri Keuangan Republik Indonesia berdasarkan Surat Keputusan No. 232/KMK.010/1992, tanggal 18 Maret 1992. PT Bursa Eek Jakarta diswastakan sepenuhnya pada tanggal 13 Juli 1992.

Pada awalnya Bursa Efek didirikan oleh Belanda di Batavia pada tahn 1912 dengan nama Vereniging Voor De Effecten. Kemudian dilanjutkan dengan didirikannya bursa di Surabaya 
dan Semarang pada tahun 1925. Namun akibat Perang Dunia II, semua bursa ditutup. Pada Tahun 1950 diaktifkan kembali dan kembali diberhentikan pada tahun 1958. Pada tanggal 10 Agustus 1977 pasar modal kembali diaktifkan.

Sejak Bursa Efek Jakarta kembali diaktifkan, operasi perdagangan efek dilakukan secara manual, yaitu order jual dan beli dipertemukan dengan menggunakan papan berdasarkan prioritas, harga dan waktu. Perdagangan dengan cara manual ini pada mulanya dapat berjalan dengan lancar mengingat jumlah efek yang tercatat di bursa serta jumlah pialang yang terlibat dilantai bursa masih terbatas. Perkembangan pasar modal terjadi pada tahunn 1989, dimana jumlah efek dan pialang berkembang pesat. Pada akhir Desember 1994 jumlah emitten tercatat 217 emitten dengan sekitar 260 perusahaan pialang yang menjadi anggota di Bursa Efek Jakarta pada akhir Juli 1995.

Menurut pertimbangan diatas serta strategi pengembangan Bursa Efek Jakata pada tahun 1995 mulai diberlakukan sistem JATS (Jakarta Automatic Tradding System). Suatu sistem perdagangan di lantai bursa yang secara otomatis memadukan antara harga jual dan beli saham. Kemudian seiring dengan kemajuan teknologi, bursa kini menggunakan sistem Remote Tradding, yaitu sistem perdagangan jarak jauh.

Bursa Efek Jakarta melakukan merger dengan Bursa Efek Surabaya pada akhir 2007 dan pada awal 2008 berubah nama menjadi Bursa Efek Indonesia

2. PT. Darya-Varia Laboratoria, Tbk

$\begin{array}{cr}\text { PT } & \text { Darya-Varia } \\ \text { Laboratoria } & \text { Tbk }\end{array}$ ("Perusahaan") didirikan dalam rangka Undang-undang Penanaman Modal Dalam Negeri No. 6 tahun 1968 berdasarkan akta notaris No. 5 tanggal 5 Februari 1976 dari notaris Abdul Latief, S.H. Akta ini disetujui oleh Menteri Kehakiman dalam Surat Keputusan No. Y.A. 5/288/11 tanggal 28 Mei 1976 dan diumumkan dalam Tambahan No. 712 pada Berita Negara No. 92 tanggal 18 November 1977. Anggaran Dasar Perusahaan telah beberapa kali diubah, antara lain mengenai perubahan nama Perusahaan menjadi PT Darya-Varia Laboratoria Tbk dan perubahan anggaran dasar Perusahaan dalam rangka Undang-undang No. 1 tahun 1995 tentang Perseroan Terbatas dilakukan 
dengan akta notaris No. 107 tanggal 18 Juni 1997 dari notaris Benny Kristianto, S.H. Perubahan anggaran dasar tersebut telah disetujui oleh Menteri Kehakiman dalam Surat Keputusan No. C26441.HT.01.04.TH.97 tanggal 9 Juli 1997 dan diumumkan dalam Tambahan No. 4747 pada Berita Negara No . 81 tanggal 10 Oktober 1997. Perubahan sehubungan dengan peningkatan modal dasar Perusahaan dari Rp100.000.000.000 (Rupiah penuh) menjadi Rp280.000.000.000 (Rupiah penuh) dilakukan dengan akta notaris No. 68 tanggal 15 Juni 1998 dari notaris Benny Kristianto, S.H. Perubahan ini telah disetujui Menteri Kehakiman dalam Surat Keputusan No. C26421.HT.01.04.TH.98 tanggal 15 Juni 1998 dan diumumkan dalam Tambahan Berita Negara No. 6400 pada Berita Negara No. 92 tanggal 16 November 1998.

3. PT. HM Sampoerna, Tbk

$$
\text { Sejarah PT. Hanjaya }
$$
Mandala Sampoerna Tbk. (PT. HM Sampoerna) dimulai pada tahun 1933 oleh Liem Seeng Tee, seorang imigran asal Cina. Ia mulai membuat dan menjual rokok kretek linting tangan di rumahnya di Surabaya, Indonesia. Perusahaan kecilnya tersebut merupakan salah satu perusahaan pertama yang memproduksi dan memasarkan rokok kretek dan rokok putih secara komersial.

Rokok kretek tumbuh popular dengan pesat. Pada awal 1930-an. Liem Seeng Tee mengganti nama keluarg dan perusahaannya menjadi Sampoerna. Setelah usahanya berkembang cukup mapan, Liem Seeng Tee memindahkan tempat tinggal keluarga dan pabriknya ke sebuah kompleks gedung yang sudah terbengkalai di Surabaya. Bangunan tersebut kemudian dienovasi, dan dikenal sebagai Taman Sampoerna yang masih memproduksi SKT PT. HM Sampoerna.

Pada masa perang Dunia II dan penjajahan Jepang, Liem Seeng Tee ditahan dan usahanya ditutup oleh penjajah. Setelah perang berakhir, ia dibebaskan dan memulai usahanya kembali. Namun pada tahun 1959, tiga tahun setelh Liem Seeng Tee wafat dan setelah perang kemerdekaan berakhir pada akhir 1950-an, perusahaan Liem Seeng Tee kembali terancam bangkrut. Pada tahun tersebut, Aga Sampoerna (putera kedua Liem Seeng Tee) ditunjuk untuk menjalankan perusahaan Sampoerna dan berhasil membangunnya kembali. 
Putera kedua Aga, yaitu

Putera Sampoerna, mengambil alih kemudi PT. HM Sampoerna pada tahun 1978. Di bawah kendalinya, PT. HM Sampoerna berkembang menjadi perseroan publik dengan struktur perseroan modern dan memulai masa investasi dan ekspansi. Dalam proses, PT. HM Sampoerna memperkuat posisinya sebagai salah satu produsen rokok kretek terkemuka Indonesia.

Pada bulan Mei 2005, PT Philip Moris Indonesia (anak perusahaan Philip Morris International Inc.), PT. HM Sampoerna telah berhasil memanfaatkan sinergi yang dihasilkan dari akuisisi secara efektif, dan pada saat bersamaan juga tetap menjaga budaya, tradisi dan warisan Indonesia.

Hingga tahun 2006, PT.

HM Sampoerna juga telah menjalin kerjasama dengan 34 mitra Produksi Sigaret (MPS) yng memproduksi sigaret kretek tangan, di berbagai wilayah di Pulau Jawa. Ke-34 MPS tersebut mempekerjakan lebih dari 55.000 karyawan.

4. PT. Kimia Farma (Persero), Tbk

PT Kimia Farma (Persero) Tbk selanjutnya disebut "Perusahaan" didirikan berdasarkan akta No. 18 tanggal 16 Agustus 1971 dan diubah dengan akta perubahan
No. 18 tanggal 11 Oktober 1971 keduanya dari Notaris Soelaeman Ardjasasmita, di Jakarta. Akta perubahan ini telah mendapat persetujuan dari Menteri Kehakiman Republik Indonesia dengan Surat Keputusan No. J.A.5/184/21 tanggal 14 Oktober 1971, yang didaftarkan pada buku registrasi No. 2888 dan No. 2889 tanggal 20 Oktober 1971 di Kantor Pengadilan Negeri Jakarta serta diumumkan dalam Berita Negara Republik Indonesia No. 90 tanggal 9 Nopember 1971 dan Tambahan Berita Negara Republik Indonesia No. 508. Anggaran Dasar Perusahaan telah beberapa kali mengalami perubahan. Perubahan tentang modal disetor terakhir dengan akta No..45 tanggal 24 Oktober 2001 dari Imas Fatimah, SH, notaris di Jakarta,. Akta perubahan ini telah mendapat persetujuan dari Menteri Kehakiman dan Hak 61 Asasi Manusia Republik Indonesia dengan Surat Keputusan No. C12746HT.01.04.TH.2001 tanggal 8 Nopember 2001. Pada tahun 2007, Anggaran Dasar mengalami perubahan dengan akta No. 29 tanggal 24 Juli 2007 dari Imas Fatimah, SH, notaris di Jakarta, mengenai perubahan Pasal 11, Pasal 12, Pasal 14, dan Pasal 15. Akta perubahan ini telah mendapat persetujuan dari 
Menteri Kehakiman dan Hak Asasi Manusia Republik Indonesia dengan Surat Keputusan No. W7-HT.01.0411423 tanggal 1 Agustus 2007. Perusahaan berdomisili di Jakarta dan memiliki unit produksi yang berlokasi di Jakarta, Bandung, Semarang, Watudakon (Mojokerto) dan Tanjung Morawa - Medan. Perusahaan juga memiliki satu unit distribusi yang berlokasi di Jakarta. Pada tahun 2003, Perusahaan membentu $\mathrm{k} 2$ (dua) Anak Perusahaan yaitu PT KFTD dan PT Kimia Farma Apotek yang sebelumnya masing-masing merupakan unit usaha Pedagang Besar Farmasi dan Apotek.

5. PT. Martino Berto, Tbk

Perusahaan ini didirikan pada tahun 1977 oleh Dr HC. Martha Tilaar, (Alm) Pranata Bernard, dan Theresa Harsini Setiady. Pada tahun 1981, perusahaan mendirikan pabrik modern pertama di Jl. Pulo Ayang No 3, Pulogadung Industrial Estate, yang memproduksi kosmetik dan jamu dengan merek "Sariayu Martha Tilaar" untuk pertama kalinya. Pada tahun 1986, Perusahaan mendirikan pabrik modern kedua di Jl. Pulo Kambing, Kawasan Industri Pulogadung ("Pabrik Pulo Kambing"). Karena pertumbuhan penjualan yang pesat, pada tahun 1995, perusahaan mengalihkan produksi herbal untuk Gunung Putri, Bogor. Sementara factrory Pulo Ayang ditransfer ke anak perusahaan, yaitu PT Cempaka Belkosindo Indah. Ini memproduksi kosmetik dengan merek "Mirabella" dan "Cempaka". Pada tahun 2005, PT Cempaka Indah Belkosindo digabung dengan perusahaan sehingga merek "Mirabella" dan "Cempaka" juga dikombinasikan dengan produksi di pabrik Pulo Kambing. Selanjutnya, Pulo Ayang pabrik dialihkan dan memungkinkan sebagai kantor penjualan samping untuk perusahaan Distribution Center, yang terletak di Jl. Pulo Ayang No 24-25, Kawasan Industri Pulogadung.

6. PT. Merck, Tbk

Didirikan pada tahun 1970, PT Merck Tbk menjadi perusahaan publik pada tahun 1981, dan merupakan salah satu perusahaan pertama yang terdaftar di Bursa Saham Indonesia. Sebagian besar saham dimiliki oleh Grup Merck yang berkantor pusat di Jerman dan merupakan perusahaan farmasi dan kimia tertua di dunia.

Perusahaan

berkedudukan di Indonesia dan berlokasi di Jl. T.B. Simatupang No. 8, Pasar Rebo, Jakarta Timur, didirikan dalam rangka penanaman modal asing 
berdasarkan Undang-Undang No. 1 tahun 1967 jo. Undang Undang No. 11 tahun 1970, dengan akte notaris Eliza Pondaag SH tanggal 14 Oktober 1970 No. 29. Akte ini disetujui oleh Menteri Kehakiman dengan No. J.A.5/173/6 tanggal 28 Desember 1970, dan diumumkan dalam Tambahan No. 202 pada Berita Negara No. 34 Anggaran Dasar Perseroan telah mengalami beberapa kali perubahan, terakhir dengan akte notaris Aulia Taufani SH, pengganti Sutjipto SH tanggal 4 Juni 2002 No.)1 mengenai perubahan nama Perseroan dari PT Merck Indonesia 62 Tbk menjadi PT Merck Tbk. Akte ini telah disetujui oleh Menteri Kehakiman dan Hak Asasi Manusia dengan No. C-11973 HT.01.04.TH.2002 tanggal 2 Juli.

7. PT. Mandom Indonesia, Tbk

PT Mandom Indonesia Tbk didirikan dalam rangka Undang-Undang Penanaman Modal Dalam Negeri No. 1 tahun 1967 jo. Undang-Undang No. 11 tahun 1970, berdasarkan akta No. 14 tanggal 5 November 1969 dari Abdul Latief, S.H., notaris di Jakarta.

Perusahaan berdomisili di Jakarta dengan pabrik berlokasi di Jakarta dan Kawasan Industri MM2100,
Cibitung, Jawa Barat. Kantor pusat Perusahaan terletak di Jl. Yos Sudarso By Pass, Jakarta.

Ruang lingkup kegiatan perusahaan terutama meliputi produksi dan perdagangan kosmetika, wangi-wangian, bahan pembersih dan kemasan plastik. Perusahaan mulai berproduksi secara komersial pada bulan April 1971. Pabrik yang berlokasi di Cibitung mulai beroperasi secara komersial pada 4 Januari 2001.

8. PT. Unilever Indonesia, Tbk PT Unilever Indonesia Tbk ("Perseroan") didirikan pada tanggal 5 Desember 1933 dengan nama Lever's Zeepfabrieken N.V. dengan akta No. 23 Mr. A.H. van Ophuijsen, notaris di Batavia, disetujui oleh Gouverneur Generaal van NederlandschIndie dengan surat No.14 tanggal 16 Desember 1933, didaftarkan di Raad van Justitie di Batavia dengan No. 302 pada tanggal 22 Desember 1933 dan diumumkan dala $\mathrm{m}$ Javasche Courant tanggal 9 Januari 1934 Tambahan No. 3. Nama Perseroan diubah menjadi "PT Unilever Indonesia" dengan akta No. 171 tanggal 22 Juli 1980 dari notaris Ny. Kartini Muljadi SH. Selanjutnya perubahan nama Perseroan menjadi "PT Unilever Indonesia Tbk", dilakukan dengan akta No. 92 tanggal 30 Juni 1997 dari 
notaris Tn. Mudofir Hadi SH. Akta ini disetujui oleh Menteri Kehakiman dalam surat keputusan No. C21.049HT.01.04 TH.98 tanggal 23 Februari 1998 dan diumumkan dalam Berita Negara No. 39 tanggal 15 Mei 1998 Tambahan No. 2620.

Pada tanggal 16

November 1981 Perseroan mendapat izin Ketua Badan Pengawas Pasar Modal (Bapepam) No.SI009/PM/E/1981 untuk menawarkan $15 \%$ sahamnya di Bursa Efek di Indonesia. Berdasarkan Rapat Umum Pemegang Saham Tahunan tanggal 13 Juni 2000, para pemegang saham menyetujui untuk melakukan pemecahan saham (stock split) dengan merubah nilai nominal saham dari Rp 1.000 (nilai penuh) menjadi Rp 100 (nilai penuh) per lembar saham. Perubahan ini diakta kan dengan akta notaris Singgih Susilo SH No. 19 tanggal 4 Agustus 2000 dan disetujui oleh Menteri Hukum dan Perundang-undangan (dahulu Menteri Kehakiman) Republik Indonesia dalam surat keputusan No. C-18481 HT.01.04-TH.2000.

Kegiatan usaha

Perseroan meliputi bidang pembuatan, pemasaran dan distribusi barang-barang konsumsi yang meliputi sabun, deterjen, margarin, dan makanan berinti susu, es krim, minuman dengan bahan pokok teh dan produk - produk kosmetik.

9. PT. Indofood CBP Sukses Makmur, Tbk PT. Indofood CBP Sukses Makmur Tbk. merupakan produsen berbagai jenis makanan dan minuman yang bermarkas di Jakarta, Indonesia. Perusahaan ini didirikan pada tanggal $\underline{14}$

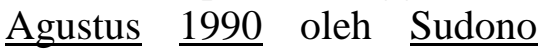
Salim dengan nama PT. Panganjaya Intikusuma yang pada tanggal 5 Februari 1994 menjadi Indofood Sukses Makmur. Perusahaan ini mengekspor bahan makanannya hingga Australia, Asia, dan Eropa. Dalam beberapa dekade ini Indofood telah bertransformasi menjadi sebuah perusahaan total food solutions dengan kegiatan operasional yang mencakup seluruh tahapan proses produksi makanan, mulai dari produksi dan pengolahan bahan baku hingga menjadi produk akhir yang tersedia di rak para pedagang eceran.

10. PT. Indofood Sukses Makmur, Tbk Perusahaan yang menjual produk seperti indomie, sarimi, supermie, dan lain-lain yang mengendalikan 90\% pangsa pasar mie di Indonesia. Perusahaan juga menghasilkan 52 bumbu 
indofood dan saus piring lombok. Produk lain mencakup chiki, chitato, cheetos, jetz, makanan bayi, kopi tugu lawak dan cafela. Perusahaan memiliki 12 cabang perusahaan yang terdiri dari : PT. Ciptakemas Abadi, PT. Gizindo Primanusantara, PT. Intipangan Prima Sejati, PT. Intranusa Cipta, PT. Tristara Mkmur, PT. Indosentra Pelangi dimana kepemilikan sebesar 70\%, PT. Arthanugraha Mandiri dimana jumlah kepemilikan 50\%, PT. Suryapangan Indonesia, PT. Cemako Mandiri dan PT. Putri Usahatama.

11. PT. Tempo Scan Pacific, Tbk

PT Tempo Scan Pacific Tbk (Perusahaan) didirikan di Republik Indonesia pada tanggal 20 Mei 1970, dengan nama PT Scanchemie dalam rangka Penanaman Modal Dalam Negeri No. 6 Tahun 1968, yang diubah dengan Undang-Undang No. 12 Tahun 1968, yang diubah dengn Undang-Undang No. 12 Tahun 1970, berdasarkan akta notaris
Ridwan Suselo, S.H., No. 37. Akta pendirian ini disahkn oleh Menteri Kehakiman Republik Indonesia dengan Surat Keputusan No J.A.5/27/4 tanggal 13 Februari 1971, dan diumumkan dalam Berita Negara Republik Indonesia No. 25, Tambahan No. 148 tanggal 26 Maret 1971. Ruang lingkup kegiatan perusahaan bergerak dalam bidang usaha farmasi dan memuli kegiatan komersialnya sejak tahun 1970. Kantor pusat Perusahaan di Gedung Bin Mulia II, lantai 5, Jl. H.R. Rasuna Said Kav. 11, Jakarta 12950, sedangkan lokasi pabriknya terletak di Cikarang-Jawa Barat.

\section{H. Deskriptif \\ Variabel} Penelitian

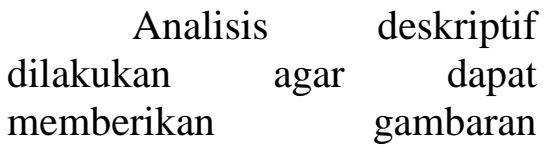
terhadap variabel-variabel yang digunakan dalam penelitian. Berdasarkan hal tersebut diatas untuk mengetahui nilai minimum, maximum, mean dan standar deviasi digunakan data tabel berikut ini :

\section{Hasil Uji Statistik Deskriptif \\ Descriptive Statistics}

\begin{tabular}{|l|r|r|r|r|r|}
\hline & \multicolumn{1}{|c|}{$\mathrm{N}$} & \multicolumn{1}{c|}{ Minimum } & \multicolumn{1}{c|}{ Maximum } & \multicolumn{1}{c|}{ Mean } & \multicolumn{1}{c|}{ Std. Deviation } \\
\hline LABA KOTOR & 30 & $141,247,744$ & $18,507,288,000,000$ & $5,043,443,212,854.67$ & $5,913,394,743,382.152$ \\
LABA TUNAI & 30 & $138,968,067$ & $11,088,270,000,000$ & $2,247,130,705,971.17$ & $3,033,544,090,518.034$ \\
LABA SETELAH & 30 & $107,808,155$ & $9,945,296,000,000$ & $1,988,026,324,928.53$ & $2,720,773,237,598.951$ \\
PAJAK & 30 & $99,993,600$ & $8,064,720,000,000$ & $1,341,133,071,895.43$ & $2,337,395,776,523.268$ \\
DIVIDEN KAS & 30 & & & & \\
Valid N (listwise) & & & \\
\hline
\end{tabular}

Sumber : Print Out Spss (2014) 
Berdasarkan tabel tersebut dapat diinterpretasikan sebagai berikut :

a. Variabel Laba Kotor

Dengan memperlihatkan jumlah data yang masuk (N) dalam pengujian ini terdapat 30 data untuk semua variabel, pada variabel laba kotor memiliki nilai terendah atau minimum yaitu sebesar Rp. 141,247,744 dan nilai tertinggi atau maximum sebesar Rp. 18,507,288,000,000. Untuk nilai mean (Rata-rata) sebesar Rp. $5,043,443,212,854.67$, sedangkan nilai standar deviasi yang merupakan simpangan baku atau penyimpangan data dari masing-masing variabel sebesar Rp. $5,913,394,743,382.152$.

b. Variabel Laba Tunai

Pada variabel laba tunai memiliki nilai terendah atau minimum yaitu sebesar Rp. 138,968,067 dan nilai tertinggi atau maximum sebesar Rp. 11,088,270,000,000. Untuk nilai mean (Rata-rata) sebesar Rp. 2,247,130,705,971.17, sedangkan nilai standar deviasi yang merupakan simpangan baku atau penyimpangan data dari masing-masing veriabel sebesar Rp. 3,033,544,090,518.034.

c. Variabel Laba Setelah Pajak

Pada variabel laba setelah pajak memiliki nilai terendah atau minumum yaitu sebesar Rp.107,808,155 dan nilai tertinggi atau maximum sebesar Rp. 9,945,296,000,000. Untuk nilai mean (Rata-rata) sebesar Rp. $\quad 1,988,026,324,928.53$, sedangkan nilai standar deviasi yang merupakan simpangan baku atau penyimpangan data dari masing-masing variabel sebesar 2,720,773,237,598.951.

d. Variabel Dividen Kas

Pada variabel laba tunai memiliki nilai terendah atau minumum yaitu sebesar Rp. 99,993,600 dan nilai tertinggi atau maximum sebesar Rp. $8,064,720,000,000$. Untuk nilai mean (Rata-rata) sebesar Rp. 1,341,133,071,895.43,

sedangkan nilai standar deviasi yang merupakan simpangan baku atau penyimpangan data dari masing-masing veriabel sebesar

Rp. 2,337,395,776,523.268.

\section{Hasil Analisis Regresi Linear Berganda}

Pengujian terhadap hipotesis dilakukan dengan menggunakan analisis regresi berganda dengan bantuan program SPSS versi 19.00 For Windows. Hasil pengujian dapat terlihat pada tabel berikut: 
Tabel 4.2

Hasil Analisis Regresi Linier Berganda

Model Summary

\begin{tabular}{|l|r|r|r|c|}
\hline Model & R & R Square & \multicolumn{1}{|c|}{$\begin{array}{c}\text { Adjusted R } \\
\text { Square }\end{array}$} & $\begin{array}{c}\text { Std. Error of the } \\
\text { Estimate }\end{array}$ \\
\hline 1 & $.929^{\mathrm{a}}$ & .864 & .848 & $910,642,107,423.625$ \\
\hline
\end{tabular}

Coefficients $^{a}$

\begin{tabular}{|c|c|c|c|c|c|}
\hline \multirow[b]{2}{*}{ Model } & \multicolumn{2}{|c|}{ Unstandardized Coefficients } & $\begin{array}{l}\text { Standardized } \\
\text { Coefficients }\end{array}$ & \multirow[b]{2}{*}{$\mathrm{t}$} & \multirow[b]{2}{*}{ Sig. } \\
\hline & $\mathrm{B}$ & Std. Error & Beta & & \\
\hline 1 (Constant) & $38,273,528,405.943$ & $229,970,123,712.489$ & & .166 & .869 \\
\hline Laba Kotor & -.373 & .135 & -.943 & -2.756 & .011 \\
\hline Laba Tunai & .242 & .138 & .314 & 1.757 & .091 \\
\hline Laba Setelah Pajak & 1.328 & .246 & 1.545 & 5.391 & .000 \\
\hline
\end{tabular}

a. Dependent Variable: Dividen Kas

Sumber : Print Out Spss (Data diolah 2014)

Dari tabel diatas, dapat

ditentukan persamaan regresi

sebagai berikut :

$\mathrm{Y}=\mathrm{Rp} .38,273,528,405.943-$

$0.373 \mathrm{X}_{1}+0.242 \mathrm{X}_{2}+1.328 \mathrm{X}_{3}$

$+\mathrm{e}$

3. Laba Tunai $\left(\mathrm{X}_{2}\right)$ sebesar 0.242 menunjukkan bahwa setiap kenaikan laba tunai sebesar Rp. 1.00 maka dividen kas akan mengalami kenaikan sebesar 0.242 dengan asumsi variabel lain tetap.

berganda di atas diperoleh :

1. Konstanta sebesar Rp. $38,273,528,405.943$

menunjukkan bahwa jika variabel independen yaitu laba kotor, laba tunai dan laba setelah pajak nilainya adalah nol maka dividen kas menunjukkan tetap sebesar Rp. 38,273,528,405.943.

2. Laba Kotor $\left(\mathrm{X}_{1}\right)$ sebesar 0.373 menunjukkan bahwa setiap kenaikan laba kotor sebesar $\mathrm{Rp} \quad .1 .00$ maka dividen kas menunjukkan negatif sebesar - 0.373 dengan asumsi variabel lain tetap.

4. Laba Setelah Pajak $\left(X_{3}\right)$ sebesar 1.328 menunjukkan bahwa setiap kenaikan laba tunai sebesar Rp. 1.00 maka dividen kas akan mengalami kenaikan sebesar 1.328 dengan asumsi variabel lain tetap.

5. Nilai $R$ sebesar 0.929 menunjukkan bahwa kontribusi dari berbagai variabel bebas $(\mathrm{X})$ terhadap variabel terikat $(\mathrm{Y})$ paling tinggi sebesar $92.9 \%$, hal ini mengindikasikan terjadi hubungan yang kuat antara Laba Kotor, Laba Tunai dan Laba Setelah Pajak terhadap Dividen Kas 
selama periode (2010 -

2012) pada perusahaan Barang Konsumsi yang terdaftar di Bursa Efek Indonesia.

6. Nilai koefisien determinasi $\mathrm{R}^{2}$ sebesar 0.864 atau 86,4 $\%$, yang menunjukkan bahwa kontribusi yang diberikan oleh Laba Kotor, Laba Tunai dan Laba Setelah Pajak adalah sebesar $86.4 \%$ dalam menjelaskan naik turunnya Dividen Kas. Sedangkan sisanya sebesar $14 \%$ dipengaruhi oleh faktor lain diluar penelitian ini.

\section{K. Uji Asumsi Klasik}

1. Uji Multikolinieritas

Untuk mengetahui suatu model regresi bebas dari multikolinearitas, yaitu mempunyai nilai VIF (Variance Inflation Factor) kurang dari 10 dan mempunyai angka Tolerance lebih dari $10 \% \quad(0,1)$. Hasil pengujian dapat dilihat pada tabel :

Tabel 4.3

Hasil Analisis Multikolinieritas

Coefficients $^{\mathrm{a}}$

\begin{tabular}{|c|c|c|c|c|c|c|c|}
\hline \multirow[b]{2}{*}{ Model } & \multicolumn{2}{|c|}{ Unstandardized Coefficients } & \multirow{2}{*}{$\begin{array}{c}\begin{array}{c}\text { Standardized } \\
\text { Coefficients }\end{array} \\
\text { Beta }\end{array}$} & \multirow[b]{2}{*}{$\mathrm{t}$} & \multirow[b]{2}{*}{ Sig. } & \multicolumn{2}{|c|}{$\begin{array}{l}\text { Collinearity } \\
\text { Statistics }\end{array}$} \\
\hline & B & Std. Error & & & & Tolerance & VIF \\
\hline $1 \quad$ (Constant) & $38,273,528,405.943$ & $229,970,123,712.489$ & & .166 & .869 & & \\
\hline LABA KOTOR & -.373 & .135 & -.943 & -2.756 & .011 & .045 & 22.382 \\
\hline LABA TUNAI & .242 & .138 & .314 & 1.757 & .091 & .164 & 6.109 \\
\hline $\begin{array}{l}\text { LABA SETELAH } \\
\text { PAJAK }\end{array}$ & 1.328 & .246 & 1.545 & 5.391 & .000 & .064 & 15.699 \\
\hline
\end{tabular}

a. Dependent Variable: DIVIDEN KAS

Sumber : Print Out Spss (Data diolah 2014)

Hasil pengujian yang dilakukan terlihat bahwa ada 2 variabel independen nilai tolerance yang kurang dari 0.10 dan ada angka VIF yang lebih dari 10 dan 1 variabel independen nilai tolerance yang lebih

dari 0.10 dan ada angka VIF yang kurang dari 10, maka dapat disimpulkan bahwa tidak ada multikolinearitas antar variabel independen dalam model regresi. 
2. Uji Heteroskedastisitas

\section{Tabel 4.5 \\ Hasil Analisis Heteroskedastisitas}

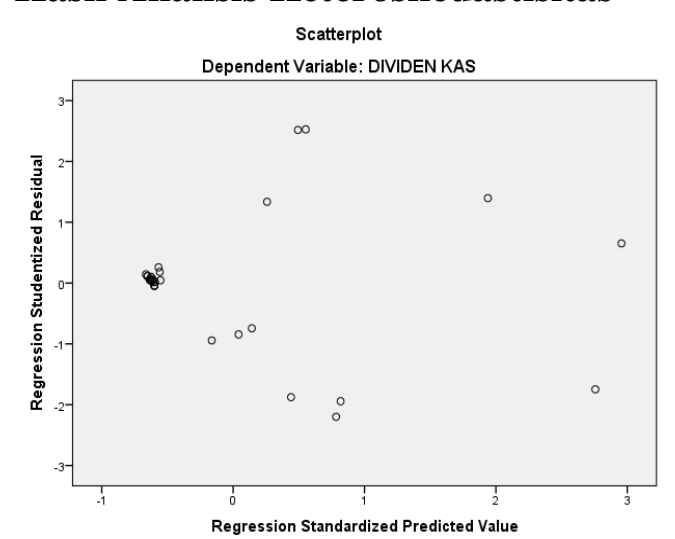

Sumber : Print Out Spss (Data diolah 2014)

Hasil pengujian heterokedastisitas dengan jelas menunjukan bahwa tidak ada pola yang jelas, serta titik menyebar diatas dan dibawah angka nol pada sumbu Y. Dengan demikian, dapat disimpulkan bahwa tidak terjadi heterokedastisitas dalam model regresi tersebut.

3. Uji Autokorelasi

Uji autokorelasi bertujuan untuk menguji apakah dalam suatu model regresi terdapat kesalahan pengganggu pada periode $t$ dengan periode $t-1$ sebelumnya. Pengujian data untuk autokorelasi ini dilakukan dengan uji DurbinWatson. Autokorelasi tidak terjadi apabila angka D-W berada diantara -2 sampai +2. Jika angka D-W dibawah -2 berada ada autokorelasi positif dan jika angka D-W diatas +2 berarti ada autokorelasi negatif. Hasil pengujian dapat dilihat pada tabel berikut ini :

\section{Tabel 4.4}

Hasil Analisis Autokorelasi

Model Summary ${ }^{b}$

\begin{tabular}{|l|r|r|r|r|r|}
\hline Model & R & R Square & \multicolumn{1}{|c|}{$\begin{array}{c}\text { Adjusted R } \\
\text { Square }\end{array}$} & $\begin{array}{c}\text { Std. Error of the } \\
\text { Estimate }\end{array}$ & $\begin{array}{c}\text { Durbin- } \\
\text { Watson }\end{array}$ \\
\hline 1 & $.929^{\mathrm{a}}$ & .864 & .848 & $910,642,107,423.625$ & 2.036 \\
\hline
\end{tabular}

a. Predictors: (Constant), Laba Setelah Pajak, Laba Tunai, Laba Kotor

b. Dependent Variable: Dividen Kas

Berdasarkan hasil Uji yang dilakukan dapat dilihat bahwa nilai Durbin-Watson adalah 2.036 ini berada diantara +2 sampai -2 maka dapat disimpulkan bahwa model regresi berarti terjadi autokorelasi.
L. Uji Hipotesis

1. Uji Secara Simultan (Fisher-tes)

Teknik analisis yang dipergunakan membuktikan 
kebenarannya adalah analisis persamaan regresi linier berganda. Uji ini digunakan untuk mengetahui apakah variabel-variabel bebas memiliki pengaruh secara bersama-sama terhadap variabel terikatnya.

Metode yang digunakan adalah dengan membandingkan $\quad F_{\text {hitung }}$ terhadap $F_{\text {tabel }}$. jika $F_{\text {hitung }}$ lebih besar dari $\mathrm{F}_{\text {tabel }}$ maka variabel bebas memiliki pengaruh secara simultan terhadap variabel terikatnya (Ho ditolak, Ha diterima). Dan sebaliknya jika $F_{\text {hitung }}$ lebih kecil dari $\mathrm{F}_{\text {tabel }}$ maka variabel bebas tidak ada pengaruh yang signifikan secara simultan terhadap variabel terikatnya (Ho diterima, $\mathrm{Ha}$ ditolak).

\section{Tabel 4.6}

Hasil Uji F

ANOVA $^{a}$

\begin{tabular}{|c|c|c|c|c|c|c|}
\hline \multicolumn{2}{|c|}{ Model } & Sum of Squares & $\mathrm{df}$ & Mean Square & $\mathrm{F}$ & Sig. \\
\hline 1 & & $\begin{array}{r}13687815622401900000 \\
0000000.000\end{array}$ & 3 & $\begin{array}{r}4562605207467300000 \\
0000000.000\end{array}$ & 55.020 & $.000^{\mathrm{b}}$ \\
\hline & Residual & $\begin{array}{r}21560995243136475000 \\
000000.000\end{array}$ & 26 & $\begin{array}{r}8292690478129413000 \\
00000.000\end{array}$ & & \\
\hline & Total & $\begin{array}{r}15843915146715548000 \\
0000000.000\end{array}$ & 29 & & & \\
\hline
\end{tabular}

a. Dependent Variable: DIVIDEN KAS

b. Predictors: (Constant), LABA SETELAH PAJAK, LABA TUNAI, LABA KOTOR

Sumber : Print Out Spss (Data diolah 2014)

Berdasarkan

perhitungan SPSS

diperoleh $F_{\text {hitung }}$ sebesar 55.020 dan $\mathrm{F}_{\text {tabel }}$ dengan $\alpha=$ $5 \%$ diperoleh $\mathrm{F}_{\text {tabel }}$ sebesar 2.975 . Artinya $\mathrm{F}_{\text {hitung }}$ lebih besar dari $\mathrm{F}_{\text {tabel }}(55.020>$ 2.975).

$$
\text { Maka hipotesis }
$$

menyatakan bahwa diduga variabel Laba Kotor, Laba Tunai dan Laba Setelah Pajak secara simultan memiliki pengaruh yang signifikasi terhadap Dividen Kas bahwasanya adalah benar.
2. Uji Secara Parsial (Student - tes)

Uji hipotesis secara parsial dilakukan dengan membandingkan besarnya nilai thitung dengan nilai tabel , dimana kriteria Ho diterima jika thitung lebih kecil dari tabel dan sebaliknya Ho ditolah jika thitung lebih besar dari tabel.

Tingkat signifikasi yang digunakan adalah alpa $(\alpha)=5 \%$ dengan tingkat kepercayaan (level of confidence $)=95 \%$ dengan derajat bebas $\mathrm{n}-1$. Hasil 
perhitungan thitung dibandingkan dengan $t_{\text {tabel }}$ pada derajat bebas dan kesalahan tersebut diatas. Jika $t_{\text {hitung }}>\mathrm{t}_{\text {tabel }}$, maka Ho akan ditolak dan $\mathrm{Ha}$ diterima berarti signifikan, sedangkan Jika $t_{\text {hitung }}<$ $\mathrm{t}_{\text {tabel , maka Ho akan }}$ diterima dan $\mathrm{Ha}$ ditolak berarti tidak signifikan.

Untuk melihat hasil uji secara parsial variabel laba tunai dapat dilihat pada table berikut :

Tabel 4.7

Hasil Uji T

Coefficients $^{a}$

\begin{tabular}{|c|c|c|c|c|c|}
\hline \multirow[b]{2}{*}{ Model } & \multicolumn{2}{|c|}{ Unstandardized Coefficients } & $\begin{array}{c}\text { Standardized } \\
\text { Coefficients }\end{array}$ & \multirow[b]{2}{*}{$\mathrm{t}$} & \multirow[b]{2}{*}{ Sig. } \\
\hline & $\mathrm{B}$ & Std. Error & Beta & & \\
\hline $1 \quad$ (Constant) & $38,273,528,405.943$ & $229,970,123,712.489$ & & .166 & .869 \\
\hline LABA KOTOR & -.373 & .135 & -.943 & -2.756 & .011 \\
\hline LABA TUNAI & .242 & .138 & .314 & 1.757 & .091 \\
\hline $\begin{array}{l}\text { LABA SETELAH } \\
\text { PAJAK }\end{array}$ & 1.328 & .246 & 1.545 & 5.391 & .000 \\
\hline
\end{tabular}

a. Dependent Variable: DIVIDEN KAS

Sumber : Print Out Spss (Data diolah 2014)

Berdasarkan hasil uji secara parsial, terbukti dengan variabel Laba

Setelah Pajak mempunyai thitung sebesar 5.391 dan $t_{\text {tabel }}$ sebesar 2.056, yang berarti $t_{\text {hitung }}$ lebih besar dari $t_{\text {tabel }}$ (5.391 < 2.056) maka hipotesis penelitian yang mengatakan variabel Laba Setelah Pajak mempunyai pengaruh signifikasi secara parsial adalah benar, dengan taraf signifikasi sebesar 0.05 atau $5 \%$ maka diperoleh hasil uji sebagai berikut :

1. Variabel Laba Kotor

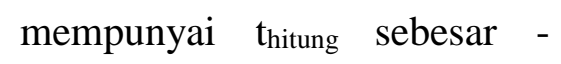
$2.756<2.056$ berarti tidak ada hubungan yang signifikan secara parsial Laba Kotor terhadap Dividen Kas pada perusahaan Barang Konsumsi .

2. Variabel Laba Tunai mempunyai thitung sebesar 0.314 $<2.056$ berarti tidak ada

\section{KESIMPULAN DAN SARAN}

M. Kesimpulan

hubungan yang signifikan secara parsial Laba Tunai terhadap Dividen Kas pada perusahaan Barang Konsumsi .

3. Variabel Laba Setelah Pajak mempunyai $t_{\text {hitung }}$ sebesar 5.391 $>2.056$ berarti memiliki hubungan yang signifikan secara parsial Laba Setelah pajak terhadap Dividen Kas pada perusahaan Barang Konsumsi. 
yang ditimbulkan oleh Laba Kotor, Laba Tunai dan Laba Setelah Pajak terhadap Dividen Kas ini menunjukkan bahwa naik turunnya Dividen Kas perusahaan Barang Konsumsi yang terdaftar di Bursa Efek Indonesia periode pengamatan 2010 2012 dipengaruhi oleh Laba Kotor, Laba Tunai dan Laba Setelah Pajak sedangkan sisanya dipengaruhi oleh faktor lain yang berasal dari diluar penelitian ini.

2. Berdasarkan pengujian hipotesis secara simultan (uji F) yang telah dianalisis diperoleh bahwa variabel Laba Kotor, Laba Tunai dan Laba Setelah Pajak memiliki pengaruh yang signifikan terhadap Dividen Kas perusahaan Barang Konsumsi yang terdaftar di Bursa Efek Indonesia periode pengamatan 2010 2012 maka dapat disimpulkan hipotesis yang pertama dalam penelitian ini terbukti kebenarannya.

3. Berdasarkan pengujian hipotesis secara parsial (uji t) bahwa variabel Laba Laba Setelah Pajak secara parsial memiliki pengaruh yang signifikan secara parsial terhadap Dividen Kas pada perusahaan Barang Konsumsi yang terdaftar di Bursa Efek Indonesia periode pengamatan 2010 2012. Maka dapat disimpulkan bahwa Hipotesis yang ke dua dalam penelitian ini terbukti kebenarannya.

\section{N. Saran}

Dari
pembahasan diatas maka dapat
diberi saran - saran sebagai
implikasi dari hasil penelitian dan
sebagai pertimbangan dalam
mengambil keputusan dalam hal
berinvestasi pada saham adalah
sebagai berikut:

1. Dalam pengambilan keputusan investasi seorang investor terlebih dahulu harus melakukan analisis terhadap faktor - faktor yang dapat mempengaruhi Laba Kotor, Laba Tunai dan Laba Setelah Pajak karena dalam penelitian ini ketiga faktor tersebut secara simultan (bersama-sama) mampu berpengaruh secara signifikan terhadap Dividen Kas perusahaan Barang Konsumsi yang terdaftar di Bursa Efek Indonesia.

2. Dengan memperhatikan faktor lain yang tidak diperhitungkan dalam penelitian ini, maka disarankan kepada investor atau calon investor agar lebih memperhatikan faktorfaktor lain tersebut, karena sekecil apapun pengaruhnya akan memberikan dampak terhadap Dividen Kas. 
3. Bagi penelitian selanjutnya, disarankan menambah variabel lain yang mempengaruhi kebijakan dividen, seperti: likuiditas perusahaan, kebijakan dividen tahun sebelumnya dengan periode waktu yang lebih banyak dari penelitian ini.

\section{DAFTAR PUSTAKA}

Belkaoui, Ahmed Riahi, 2000. Teori Akuntansi. Edisi Pertama, Penerbit Salemba Empat, Jakarta.

Evan, Thomas G., 2003. Accounting Theory: Contemporary Accounting Issues, SouthWestern, Ohio, hal 199.

Harahap, Sofyan Syafri. 2004. Analisis Kritis Atas Laporan Keuangan. Jakarta: PT Raja Grafindo Persada.

Hendriksen, Eldon $\mathrm{S}$ dan F. Van Breda, 2000, Teori Akunting, Edisi ke-5, Interaksara.

Husnan, Suad, 1994, Dasar-Dasar Manajemen Keuangan, UUPAMP, YKPN, Yogyakarta.

Ikatan Akuntan Indonesia. 2012. Standar Akuntansi keuangan per 1 Juni 2012, Salemba Empat, Jakarta.

Kieso, Donald, Jerry Weygandt, dan Terry D Warfield, 2002. Akuntansi Intermediate, Edisi Kesepuluh, Jilid 1, alih bahasa Emil Salim, Penerbit Erlangga, Jakarta.

Kotler, Philip, (1997), Manajemen

Pemasaran, Analisis
Perencanaan dan Pengendalian, Jilid 2 Edisi Kedelapan, Penerbit Erlangga,Jakarta.

Kotler, Philip, (2000), Manajemen Pemasaran, PT. Prenhallindo, Jakarta.

Mudrajat Kuncoro, 2001, Metode Kuantitatif Teori dan Aplikasi untuk Bisnis dan Ekonomi, Edisi Pertama, UPP AMP YKPN, Yogyakarta.

Muqodim, Teori Akuntansi, Edisi ke1, Ekonisia, Yogyakarta, Mei 2005.

Riyanto, Bambang, 2002. Bunga Rampai Kajian Teori Keuangan, Cetakan Pertama, BPFE UGM, Yogyakarta, hal 62.

Soemarso, S.R, 2004, Akuntansi:Suatu Pengantar. Edisi Kelima, Buku 1, Penerbit Salemba Empat, Jakarta.

Sugiyono, 2008, Metode Penelitian

Bisnis. Cetakan Keduabelas, Penerbit Alfabeta, Bandung.

Suwardjono. 2005, Teori Akuntansi Perekayasaan Pelaporan

Keuangan. Edisi ke- 3. Yogyakarta.

Wild, J J, et.al. 2005. Financial Statement Analysis. Penerbit Salemba Empat, Jakarta. http://sahamok.com. Diakses 27 Maret 2014

http://www.idx.co.id. Diakses 15 Maret 2014 